\title{
RELEVANSI PEMIKIRAN PENDIDIKAN ISLAM HARUN NASUTION DENGAN PENDIDIKAN ERA MODERN DI INDONESIA
}

\author{
Diah Rusmala Dewi \\ diahrd95@gmail.com \\ UIN Sunan Kalijaga Yogyakarta
}

\begin{abstract}
This article aims to analyze Harun Nasution's thoughts on education and its relevance to the modern world, especially in Indonesia. The method used in this research is literature study where the author tries to find, compile and analyze various information through various related sources. The results of this study explain that according to Harun Nasution, the backwardness of Muslims in Indonesia is caused by the Islamic education system which only focuses on the teachings of worship and fiqh which have implications for Islamic teachings which are interpreted as narrow and rigid teachings so that reforms in the world of Islamic education are needed by paying attention four important things, namely: (1) the educational curriculum should be prepared by taking into account the moral aspects, development and growth of students' thought processes, (2) the use of educational methods should emphasize the cultivation of moral education so that good morals are formed in children in addition to the delivery of material, (3) educators should have various competencies and constantly improve their quality, (4) religious education should produce students or students who religious spirit, not just religious knowledge. The positive impact expected in this article emphasizes the importance of moral aspects to be instilled in students to answer the problem of moral decline that is increasingly prevalent in this modern era.
\end{abstract}

Keywords: Harun Nasution's, Education, Modern Era.

\begin{abstract}
Abstrak
Artikel ini bertujuan untuk menganalisis tentang pemikiran Harun Nasution mengenai pendidikan dan relevansinya dengan dunia modern khususnya di Indonesia. Metode yang digunakan dalam penelitian ini adalah studi pustaka dimana penulis berusaha menemukan, menyusun dan menganalisis berbagai informasi melalui berbagai sumber terkait. Hasil penelitian ini menjelaskan bahwa menurut Harun Nasution keterbelakangan umat Islam di Indonesia
\end{abstract}


disebabkan oleh sistem pendidikan Islam yang hanya berfokus pada ajaran-ajaran ibadah dan fiqih yang berimplikasi pada ajaran Islam dimaknai sebagai ajaran yang sempit dan kaku sehingga perlu dilakukan reformasi dalam dunia pendidikan Islam dengan memperhatikan empat hal penting yaitu: (1) kurikulum pendidikan hendaknya disusun dengan memperhatikan aspek moral, perkembangan dan pertumbuhan proses berpikir peserta didik, (2) penggunaan metode pendidikan hendaknya ditekankan pada penanaman pendidikan moral sehingga terbentuk moral yang baik dalam diri anak disamping tersampaikannya materi, (3) pendidik sudah seharusnya memiliki berbagai kompetensi dan senantiasa terus meningkatkan kualitasnya, (4) pendidikan agama seharusnya menghasilkan siswa atau mahasiswa yang berjiwa agama, bukan sekedar berpengetahuan agama. Dampak positif yang diharapkan dalam artikel ini menekankan pada pentingnya aspek moral untuk ditanamkan kepada peserta didik untuk menjawab permasalahan kemerosotan akhlak yang semakin marak terjadi di era moedern ini.

\section{Kata Kunci : Harun Nasution, Pendidikan, Era Modern}

\section{A. Pendahuluan}

Hakikat pendidikan Islam adalah usaha sadar dan terencana dengan cara menumbuhkembangkan, memperbaiki, memimpin, melatih peserta didik agar dapat mengaktualisasikan diri secara aktif untuk memiliki kekuatan spiritual keagamaan, ilmu, akhlak mulia, dan keterampilan yang diperlukan dalam menjalani hidup di dunia dan akhirat sesuai dengan nilai-nilai Islam. ${ }^{1}$ Islam menyatukan tiga hal dalam diri seseorang yakni akidah-iman, ilmu dan amal soleh. Khususnya masalah ilmu, pertama kali ayat al-Qur'an yang turun ialah berkaitan dengan ilmu. Filsafat menunjukkan bahwa kata “iqra” tidak semata-mata diartikan sebagai "bacalah” dengan mata kepala, tapi juga bisa diartikan sebagai “telitilah”, “dalamilah” serta “ketahuilah” yang tentunya dengan indera, akal dan hati. ${ }^{2}$ Dalam hal ini, Harun Nasution berpendapat bahwa akal dalam konsep Islam bukan hanya otak, tetapi daya pikir yang terdapat dalam jiwa manusia sebagai aktifitas berfikir manusia untuk memperoleh pengetahuan. ${ }^{3}$

1 Maragustam, Filsafat Pendidikan Islam Menuju Pembentukan Karakter (Yogyakarta: Pascasarjana FITK UIN Sunan Kalijaga Yogyakarta, 2018), 34.

2 Ibid, 38.

3 Depi Yanti, “Konsep Akal Dalam Perspektif Harun Nasution,” Intelektualita 6, no. 1 
Berkaitan dengan hal tersebut, pada awalnya sistem pendidikan Islam di Indonesia berfokus hanya pada ajaran-ajaran ibadah dan fiqih, yang secara umum dititik beratkan pada mazhab Syafi'i sehingga ajaran Islam dimaknai sebagai ajaran yang sempit dan kaku. Hal inilah yang kemudian melatarbelakangi pemikiran Harun Nasution terkait perlunya dilakukan reformasi dalam dunia pendidikan Islam. Harun Nasution berpendapat bahwa nilai-nilai ajaran Islam perlu disinergikan dengan pemikiran-pemikiran rasional, sebab akal memiliki peranan penting dalam mengaktualisasikan ajaran Islam yang terkandung didalam Al-Qur'an. Wahyu membutuhkan akal untuk memahami kebenaran yang terkandung di dalamnya. Demikian pula, akal membutuhkan wahyu sebagai kendali dari kesesatan berpikir. ${ }^{4}$ Menurutnya, materi pendidikan Islam di Indonesia khususnya di Perguruan Tinggi Islam perlu ditambahkan beberapa aspek penting seperti dasar-dasar hukum Islam, perbandingan mazhab, teologi dan aliran-aliran yang terdapat didalamnya, filsafat, mistisme, sejarah dan kebudayaan Islam dari zaman klasik sampai zaman modern.

Nasution berpendapat bahwa salah satu yang menyebabkan umat Islam termasuk di Indonesia mengalami keterbelakangan adalah karena kurangnya kemampuan adaptif dalam proses modernisasi dan kecenderungannya akan pandangan hidup tradisional, khususnya teologi Asy’ariyah. Oleh karena itu, pentingnya melakukan perubahan terhadap hal tersebut melalui reaktualisasi dan sosialisasi pandangan rasional yang pada dasarnya telah dikembangkan dalam teologi Mu’tazilah sehingga secara kultural, umat Islam siap terlibat dalam pembangunan dan modernisasi dengan berlandas pada tradisi sendiri. ${ }^{5}$ Harun Nasution menghendaki agar kemerdekaan berpikir, penganutan teologi yang tepat, penempatan posisi akal sesuai kebutuhannya di antara wahyu yang merupakan dasar dari pola-pola pendidikan Islam harus dihidupkan kembali. ${ }^{6}$

(2017), 53.

${ }^{4}$ Ibrahim, "Pemikiran Islam Kontemporer (Studi Kritis Terhadap Pemikiran Harun Nasution),” Jurnal Aqidah-Ta II, no. 2 (2016), 99.

5 Abdus Syakur, "Polemik Harun Nasution-H.M. Rasjidi Dalam Falsafat Dan Teologi," Jurnal Ilmu Ushuluddin 2, no. 4 (2015), 387.

${ }^{6}$ Sukma Umbara Tirta Firdaus, "Pembaharuan Pendidikan Islam Ala Harun Nasution (Sebuah Refleksi Akan Kerinduan 'Keemasan Islam’),” El-Furqania 5, no. 2 (2017), 183. 
Berdasarkan hal tersebut, penulis tertarik untuk menganalisis terkait pemikiran Harun Nasution tentang pendidikan dan relevansinya dengan dunia modern.

\section{B. Pembahasan}

\section{Kajian Teori}

\section{Biografi Harun Nasution}

Harun Nasution dikenal sebagai seorang tokoh pendidikan kenamaan Indonesia yang lahir pada hari Selasa 23 September 1919, di Pemantang Siantar, Sumatera Utara. Ayah beliau bernama Abdul Jabar Ahmad yang merupakan seorang ulama di daerah Mandailing, Tanah Bato, Tapanuli Selatan. ${ }^{7}$ Penanaman pendidikan agama Harun Nasution yang kuat tidak terlepas dari peran kedua orang tuanya. Dari segi ekonomi, ayahnya adalah seorang berkecukupan serta pernah menduduki jabatan sebagai qadhi atau hakim agama dan imam masjid di Kabupaten Simalungun. Ibunya adalah seorang keturunan ulama yang berasal dari tanah Bato Mandailing, Tapanuli selatan. Pada masa gadisnya ia pernah bermukim di Makkah dan pandai berbahasa Arab. ${ }^{8}$

Adapun latar belakang pendidikannya yaitu Harun Nasution telah menempuh beberapa pendidikan di Sekolah formal. Ia pertama kali mulai bersekolah pada usia 7 tahun di Sekolah Dasar milik Belanda atau yang sering disebut dengan Hollandsch Inlandsche School (HIS). Harun Nasution menyelesaikan studinya di sekolah tersebut selama tujuh tahun dan lulus pada usia 14 tahun. Selama mengikuti pendidikan di sekolah dasar Belanda tersebut, Ia berkesempatan mempelajari bahasa Belanda dan ilmu pengetahuan umum. Setelah itu pada tahun 1934, Ia meneruskan studinya ke Moderne Islamietische Kweekschool (MIK) yaitu sekolah guru menengah pertama swasta modern di Bukit Tinggi yang berhasil ditempuh

7 Suwito and Fauzan, Sejarah Pemikiran Para Tokoh Pendidikan (Bandung: Angkasa, 2003), 398.

${ }^{8}$ Herlina Harahap, Pembaharuan Pendidikan Islam Perspektif Harun Nasution (Pontianak: STAIN Pontianak Press, 2016), 35-36. 
selama tiga tahun dan lulus pada tahun $1937 .{ }^{9}$

Selanjutnya, pada jenjang pendidikan tinggi, Harun Nasution berkesempatan menempuh pendidikan di Universitas Al Azhar Kairo Mesir Fakultas Ushuludin pada tahun 1940. Tidak hanya bersekolah di Al Azhar saja, Harun Nasution juga berkesempatan menempuh pendidikannya di Universitas Amerika, Kairo dan memperoleh gelar Bachelor of Art (BA) dalam studi sosial pada tahun 1952. Selepas mengenyam pendidikan di Mesir, Harun Nasution kembali ke Indonesia pada tahun 1953, dan di tugaskan di Departemen Luar Negeri Bagian Timur Tengah kala itu. Sejak tahun 1955, Ia bertugas di Brussel selama tiga tahun dan banyak mewakili berbagai pertemuan, terutama karena kemampuannya dalam bahasa Belanda, Perancis serta Inggris. ${ }^{10}$

Setelah itu, Harun Nasution sempat tidak dapat melanjutkan studinya ke Mesir tepatnya di Al-Dirasah Al-Islamiyyah karena terhambat biaya. Namun demikian, akhirnya Ia menerima beasiswa dari Institute Of Islamic Studies McGill di Montreal Kanada sehingga pada tahun 1962 ia melanjutkan studinya di Universitas tersebut. Kemudian pada tahun 1965, melalui tesisnya yang berjudul The Islamic State in Indonesia : The Rise of The Ideology, The Movement for Its Creation and The Theory of The Masjumi, Harun Nasution berhasil meraih gelar Magister of Art (MA) dalam Studi Islam. Tiga tahun kemudian tepatnya pada tahun 1968, Harun Nasution mendapatkan gelar Doktor (Ph.D) dalam Studi Islam di McGill Kanada, dengan disertasi yang berjudul : The Place of Reason in Abduh's Theology. Its Impact on His Theological System and Views. ${ }^{11}$

Setelah mendapatkan gelar Doktor, pada tahun 1969 Harun Nasution kembali ke Indonesia dan melanjutkan karirnya sebagai profesional tenaga pendidikan di IAIN Jakarta. Di samping itu beliau juga menjabat sebagai tenaga pendidik (dosen luar biasa) di IKIP Jakarta pada tahun 1970, Dosen di Universitas Nasional Jakarta pada tahun 1970, dan

\footnotetext{
9 Sejarah Pemikiran Para Tokoh Pendidikan, 398.

10 Harahap, Pembaharuan Pendidikan Islam Perspektif Harun Nasution, 36-37.
} 
Dosen Fakultas Sastra di Universitas Indonesia Jakarta pada tahun 1975. Tidak hanya itu jajaran jabatan tinggi di kampus diantaranya yaitu menjadi rektor di IAIN Syarif Hidayatullah Jakarta selama 11 tahun (1973-1984) pun turut mewarnai karir beliau, selain itu beliau juga pernah menjabat sebagai ketua lembaga pembinaan pendidikan agama di IKIP Jakarta dan terakhir menjadi dosen Fakultas Pascasarjana IAIN Syarif Hidayatullah Jakarta sejak 1982 hingga akhir hayatnya pada tahun $1998 .^{12}$

Adapun beberapa karya intelektual yang telah di tulis oleh Harun Nasution dalam beberapa buku adalah sebagai berikut : Teologi Islam aliran-aliran sejarah analisis perbandingan (1972), Falsafat Agama (1973), Falsafat dan Mistisisme dalam Islam (1973), Islam ditinjau Dari Beberapa Aspek (1974), Teologi Islam (1977), Pembaruan Dalam Islam (1975), Muhammad Abduh dan Teologi Rasional Mu’tazilah (1978), Akal dan Wahyu dalam Islam (1982), Islam Rasional (1995). ${ }^{13}$

\section{Pemikiran Harun Nasution Tentang Pendidikan Islam}

\section{a. Hakikat Pembaharuan Pendidikan Islam}

Harun Nasution berkeinginan mengubah mentalitas umat, dari yang tradisional-statis menjadi modern-dinamis dengan mengganti paham teologi Asy’ariyah yang mendominasi di kalangan umat. Selanjutnya, Harun Nasution menawarkan teologi rasional yang tercermin dalam paham Mu'tazilah dimana manusia dipandang sebagai makhluk rasional yang berkehendak, berpikir, dan berbuat secara otonom tidak ditentukan oleh Tuhan. Dalam arti bahwa perbuatan manusia didasarkan oleh pertimbangan-pertimbangan rasional hingga melahirkan apa yang disebut dengan tindakan rasional. ${ }^{14}$ Namun demikian, ide pembaharuannya tersebut bukan berarti mengajak umat Islam agar menjadi pengikut Mu’tazilah, tetapi beliau mengharapkan agar umat Islam bersikap

11 Harahap, 37.

12 Harahap, 37-38.

13 Nurisman, Pemikiran Filsafat Islam Harun Nasution: Pengembangan Pemikiran Islam Di Indonesia (Yogyakarta: Teras, 2012), 87.

14 Ahmad Syadali and dkk, Refleksi Pembaharuan Pemikiran Islam 70 Tahun Harun Nasution (Jakarta: Lembaga Studi Agama dan Filsafat, 1989), 141. 
rasional dalam kehidupannya, sebagaimana agama Islam pernah mencetak sejarah yang cemerlang karena sangat menghargai akal (rasio).

Harun Nasution mengungkapkan bahwa cara pandang yang selama ini diajarkan kepada mahasiswa di IAIN adalah hanya berorientasi pada aspek fikih sehingga menimbulkan kesempitan berpikir. ${ }^{15}$ Oleh karena itu, langkah pertama yang dilakukan Harun Nasution ketika menjabat sebagai rektor di IAIN Jakarta adalah merubah kurikulum yaitu dengan memasukkan beberapa mata kuliah baru diantaranya yaitu pengantar ilmu agama, filsafat, tasawuf, ilmu kalam, tauhid, sosiologi, dan metode riset dengan harapan akan mengubah pandangan mahasiswa. Hal tersebut sempat mendapat penolakan oleh beberapa pihak, namun pada akhirnya ditemukan titik tengah dengan jalan berkompromi sehingga mencapai kesepakatan bersama yaitu dengan syarat tafsir, hadis dan fiqih tidak ditinggalkan. ${ }^{16}$

Menurutnya, kesan bahwa Islam itu sempit harus diubah dengan menampilkan ajaran Islam secara utuh, tidak terpotong-potong. Untuk itulah Harun menulis buku yang berjudul "Islam Ditinjau dari Berbagai Aspeknya“ yang terdiri dari dua jilid. Buku tersebut dijadikan sebagai buku teks wajib dalam mata kuliah Pengantar Ilmu Agama Islam yang merupakan mata kuliah yang wajib diambil oleh setiap mahasiswa IAIN, apapun fakultas dan jurusannya. Dengan demikian diharapkan sarjana yang dihasilkan oleh IAIN akan mempunyai pengetahuan yang lebih baik, luas, dan lengkap tentang agamanya sehingga melahirkan sikap mental yang lebih terbuka, tidak lagi berpandangan sempit. ${ }^{17}$

Pendekatan yang dilakukan oleh Harun Nasution dalam bukunya tersebut yaitu membagi dua ajaran Islam ke dalam dua bagian besar, yakni ajaran yang bersifat mutlak dan absolut serta ajaran yang bersifat relatif dan nisbi. Ajaran mutlak dan absolut adalah ajaran yang tidak boleh dirubah yaitu terdapat dalam al-Qur'an dan Hadis sebagai sumber utama

\footnotetext{
15 Syadali, 43.

16 Syadali, 41.
} 
Islam. Sedangkan ajaran yang bersifat relatif dan nisbi adalah ajaran yang terdapat dalam kitab-kitab fikih, tauhid, tafsir, filsafat, tasawuf, dsb. Ajaran tersebut merupakan interpretasi para ulama Islam terhadap sumber utama Islam yaitu al-Qur'an dan Hadis yang kebenaranya tidaklah mutlak. ${ }^{18}$

Berdasarkan hal tersebut, dapat disimpulkan bahwa Harun Nasution ingin mempertahankan ajaran Islam yang mutlak-absolut dan memberi ruang terhadap pemahaman dan penafsiran ajaran yang relatif untuk kemudian mendialogkan antara ajaran agama dengan realitas ajaran agama sehingga dapat memberikan alternatif untuk dapat menjawab persoalan-persolan yang dihadapi umat manusia dewasa ini.

Selanjutnya, aspek lain yang menjadi fokus perbaikan yaitu kualitas para dosen di lingkungan IAIN dimana untuk para dosen, Harun Nasution membentuk forum diskusi reguler mingguan dan bulanan, bahkan juga membentuk Forum Pengkajian Islam (FPI) sebagai media untuk memecahkan masalah-masalah krusial, sehingga didalamnya melibatkan beberapa orang yang ahli dalam bidangnya masing-masing. Secara insidental diselenggarakan pula seminar-seminar, baik yang berskala nasional maupun internasional, dengan membahas tema-tema yang kontekstual dilihat dari segi kebutuhan dan tantangan masyarakat serta ditinjau dari perspektif agama. ${ }^{19}$ Untuk meningkatan mutu tenaga pengajar, Harun Nasution juga membuka Fakultas Pasca Sarjana dengan program S2 dan S3 yang langsung beliau pimpin.

Harun Nasution dengan berbagai usahanya dalam membenahi berbagai sektor, telah melahirkan satu citra IAIN Jakarta yang menjadi identitas sekaligus yang harus terus diisi dan diperjuangkan oleh seluruh sivitas akademika. Identitas tersebut adalah "IAIN sebagai pusat studi pembaharuan pemikiran dalam Islam” sebagai usaha 
pembinaan kehidupan beragama. ${ }^{20}$

\section{b. Tujuan}

Agama, terutama Islam, menurut Harun Nasution datang ke dunia untuk membimbing manusia agar mencapai kebahagiaan dunia dan akhirat. Oleh karena itu, tujuan sebenarnya dari agama Islam adalah membina manusia agar baik dan sehat fisik maupun mental. ${ }^{21}$ Salah satunya yaitu dengan penguatan pendidikan moral. ${ }^{22}$

Karena penajaman daya pikir atau akal telah menjadi tugas ilmu pengetahuan, maka pendidikan kalbu menjadi tugas pendidikan agama untuk mengimbangi pendidikan akal agar dapat mewujudkan anak didik yang utuh dalam artian terdapat keseimbangan antara rohani dan jasmani dalam dirinya. ${ }^{23}$ Menurutnya, sebagai upaya menjawab permasalahan kemerosotan akhlak, apa yang disebut dengan pendidikan agama seharusnya menghasilkan siswa atau mahasiswa yang berjiwa agama, bukan sekedar berpengetahuan agama. ${ }^{24}$

\section{c. Kurikulum}

Penyusunan kurikulum atau silabus pendidikan agama di sekolah-sekolah umum menurut Harun Nasution sebaiknya di dasarkan pada tujuan moral, spiritual, dan intelektual dimana didasarkan pada hal-hal berikut:

Untuk pemberian materi agama di TK dan SD perlu ditekankan bahwa yang harus diperhatikan adalah pendidikan (membina) akhlak dan bukan pengajaran (memindahkan pengetahuan) akhlak. Tujuan pendidikan agama disini bukanlah menjelaskan kepada anak didik bahwa menyontek adalah perbuatan yang tidak baik, tetapi tujuannya adalah mendidik anak supaya tidak menyontek karena hal tersebut adalah perbuatan yang tidak baik. Disamping pembinaan moral, anak

19 Syadali, 276-277.

20 Syadali, 278.

21 Nasution, 422.

22 Nasution, 386.

23 Sejarah Pemikiran Para Tokoh Pendidikan, 405.

24 Nasution, Harun Nasuition, Islam Rasional : Gagasan Dan Pemikiran, 385. 
didik pada jenjang ini perlu diberikan ajaran mengenai akidah dalam bentuk sederhana dan juga ibadah dalam Islam terutama shalat dan puasa pada bulan Ramadhan. ${ }^{25}$

Di jenjang SMP dan SMA pendidikan agama yang ditekankan pada pendidikan moral dan akhlak mulia harus terus diupayakan. Pelajaran tentang akidah dan ibadah juga berlanjut. Disamping itu, diajarkan pula tentang peraturan atau hukum agama hidup bermasyarakat, seperti pernikahan, perceraian dan sebagainya. Tetapi, baik akidah dan ibadah tetap ditekankan pada pembentukan akhlak mulia. Sejarah dan peradaban agama secara ringkas dapat pula diberikan di jenjang SMA. ${ }^{26}$

Pendidikan agama di Perguruan Tinggi dilanjutkan dengan hal-hal yang bersifat filosofis seperti teologi, mistisme, dan filsafat keagamaan. Pandangan filosofis ini akan mempertebal keyakinan mahasiswa tentang agama yang dianutnya. Informasi tentang pembaruan yang dialami agama sebagai akibat kemajuan ilmu pengetahuan dan teknologi perlu diberikan sehingga memberinya kesadaran bahwa agama tidaklah bersifat statis namun tidak pula harus selalu mengikuti perkembangan zaman. ${ }^{27}$

Harun Nasution juga melakukan sebuah gebrakan dalam pengembangan sistem pendidikan di bidang akademik khususnya pendidikan perguruan tinggi. Dalam tradisi akademik perguruan tinggi Islam di Indonesia, ada tiga perubahan dan pembaharuan sistem yang diupayakannya yaitu sebagai berikut :

a. Mengupayakan strategi pembelajaran yang mengasah kemampuan berpikir mahasiswa tentang Islam seperti diskusi dan seminar.

b. Mengupayakan tumbuhnya tradisi ilmiah Upaya dengan cara mengubah sistem perkuliahan yang bercorak hapalan, texbook thinking, dan cenderung menganut mazhab-mazhab tertentu, menjadi

25 Nasution, 406-407.

26 Nasution, 407. 
sistem perkuliahan yang mengajak mahasiswa berfikir secara rasional, kritis, inovatif, objektif, dan menghargai perbedaan pendapat. ${ }^{28}$

c. Merubah budaya lisan menjadi budaya tulisan dengan cara tekun melatih mahasiswa-mahasiswanya untuk menulis pemikiran secara runtut dan sistematis sebagai upaya mengatasi kelemahan dalam budaya lisan. ${ }^{29}$

d. Mahasiswa dituntut untuk memahami Islam secara universal, tidak hanya terbatas pada bidang pemikiran saja sepeti teologi, tasawuf dan hukum fiqih, akan tetapi juga mencakup seluruh aspek kehidupan kaum muslimin ${ }^{30}$

\section{d. Metode}

Lingkungan sekolah adalah lingkungan kedua setelah keluarga, tempat pendidikan moral yang sebelumnya diajarkan di dalam keluarga dapat diteruskan oleh para pendidik di lingkungan sekolah. Harun menjelaskan bahwa tujuan pendidikan agama baik di lembaga pendidikan umum maupun pendidikan agama harus ditekankan pada upaya memperdalam daya rasa atau kalbu anak didik, sehingga menjadi manusia yang berbudi luhur dan berakhlak mulia. ${ }^{31}$

Karena tujuan utama dari pendidikan Islam adalah pendidikan moral, maka metode yang sebaiknya dipakai ialah: pemberian contoh dan teladan yang baik dari penidik agama kepada anak didik, pemberian nasihat kepada peserta didik, tuntunan dalam menyelesaikan persoalan moral atau spiritual, baik yang bersifat individual maupun kolektif, kerjasama dengan lingkungan terkait rumah dan lingkungan terkait pergaulan anak didik, kerjasama dengan berbagai pendidik lainnya, dan diskusi tanya-jawab dalam hal intelektual tentang

27 Nasution, 407.

28 Muhammad Husnol Hidayat, "Harun Nasution Dan Pembaharuan Pemikiran Pendidikan Islam,” Tadris 10, no. 1 (2015), 34.

29 Hidayat, 31.

30 Hidayat, 32.

31 Sejarah Pemikiran Para Tokoh Pendidikan, 405. 
ajaran-ajaran agama. $^{32}$

Harun Nasution menjelaskan bahwa keberhasilan pendidikan anak dimulai sejak dini. Oleh karena itu, pendidikan akhlak dan moral semestinya sudah dimulai dalam lingkungan rumah. Tugas orang tua dalam pendidikan moral tidaklah ringan karena ibu dan bapak harus memberikan contoh, sekaligus menjadi model (figur teladan) bagi anak didiknya. Identifikasi seorang anak kepada orang tua merupakan awal dari keberhasilan pendidikan agama, khususnya moral. Harun juga menyatakan bahwa ibadah yang diajarkan kepada anak tidak boleh terlepas dari pembinaan moral yang terkandung didalamnya. Maksudnya adalah menanamkan pengertian bahwa ibadah jangan sampai dimaknai oleh anak hanya sebatas perintah sesuai hukum dan bentuk formalnya saja, akan tetapi lebih kepada sasaran yang sebenarnya yaitu pembinaan moral dan akhlak yang mulia. ${ }^{33}$

Lingkungan yang kondusif sangat menunjang dalam pencapaian tujuan pendidikan. Dalam hal ini, proses pendidikan moral yang telah di transfer ke dalam keluarga maupun di sekolah diharapkan dapat diteruskan dan dilakukan oleh masyarakat sekitar anak didik. Menurutnya, Islam juga menentukan peraturan-peraturan bagi manusia dalam hidup bermasyarakat agar ia jauh dari kejahatan. Islam tidak hanya membentuk individu yang bermoral baik, tetapi juga membina masyarakat yang bermoral baik. Individu dan masyarakat mempunyai hubungan yang sangat erat. Karena individu yang bermoral baiklah yang dapat membentuk tatanan masyarakat yang baik pula. Begitupun sebaliknya.. ${ }^{34}$

\section{e. Kualitas Pendidik Agama}

Menurut Harun Nasution ada beberapa syarat-syarat yang perlu dipenuhi bagi seorang pendidik agama antara lain yaitu: (1) sanggup memeberi contoh dan teladan yang baik bagi anak didik, (2) menguasai

32 Nasution, Harun Nasuition, Islam Rasional : Gagasan Dan Pemikiran, 388.

33 Sejarah Pemikiran Para Tokoh Pendidikan, 404. 
ilmu-ilmu yang erat dengan pendidikan anak, seperti pedagogi, psikologi anak, dan sebagainya, (3) mempunyai pengetahuan yang luas tentang agama selain pengetahuan yang menjadi jurusannya, (4) mempunyai pengetahuan umum yang seimbang dengan pengetahuan yang dipelajari siswa.. ${ }^{35}$

\section{f. Peserta Didik}

Dalam ajaran agama, manusia terdiri bukan hanya dari tubuh, seperti yang terdapat dalam filsafat materialisme, tetapi dari unsur jasmani dan ruhani yang unsurnya bukan hanya tediri dari daya intelek saja seperti yang terdapat pada filsafat Barat, tetapi terdapat unsur daya berpikir yang disebut akal yang berpusat di kepala dan daya merasa yang disebut kalbu yang berpusat di dada. Daya rasa dipertajam melalui ibadah, sedangkan daya pikir dipertajam dengan berpikir secara filosofis atas dorongan ayat kawniyah (kejadian alam). ${ }^{36}$

Berdasarkan hal tersebut, peserta didik dapat dipandang sebagai seorang manusia yang harus diasah semua potensinya, baik jasmani, akal, dan yang terpenting kalbunya (hati/jiwa), sehingga pendidikan agama seharusnya menghasilkan siswa atau mahasiswa yang berjiwa agama, bukan sekedar berpengetahuan agama.

\section{Dunia Modern}

Hidup di dunia tampaknya telah sampai pada era modern yaitu era di mana kehidupan telah mengglobal ditandai dengan transportasi dan komuniasi ke segala arah yang begitu mudah, komunikasi dengan cepat, dan perdagangan bebas terjadi. ${ }^{37}$ Hampir tidak ada celah kehidupan yang belum tersentuh modernitas, termasuk aspek karakter religius. Hal tersebut dapat dijadikan alat yang sangat ampuh untuk menanamkan atau sebaliknya, merusak tatanan nilai-nilai spiritual keagamaan dan pilar-pilar karakter dimana berbagai dampak negatif dari kemajuan iptek dapat mempengaruhi dan mengontrol

34 Sejarah Pemikiran Para Tokoh Pendidikan, 407-408.

35 Nasution, Harun Nasuition, Islam Rasional : Gagasan Dan Pemikiran, 389.

36 Nasution, 400-401.

37 Amin Abdullah and dkk, Pendidikan Islam Dan Tantangan Globalisasi, Buah Pikiran 
pola pikir seseorang. ${ }^{38}$

Al-Qur'an diturunkan oleh Allah swt untuk kepentingan manusia dimana didalamnya berisi petunjuk bagaimana membentuk manusia yang berakhlak mulia. Karena pada dasarnya manusia membawa fitrah yang baik yang dapat dikembangkan ke arah yang baik. Namun dalam proses hidup manusia karena dilingkupi oleh gesekan lingkungan seperti sosial media (sosmed), sosio kultural, pendidikan, tradisi, dan lain-lain maka karakter manusia menjadi negatif tak terkontrol. ${ }^{39}$

Oleh kerena itu, peran pendidikan Islam dalam membentuk daya tahan untuk menghadapi berbagai dampak kemungkinan yang ditimbulkan dari perkembangan zaman melalui pendidikan moral atau karakter sangat diperlukan di era modern ini.

\section{Metode Penelitian}

Jenis metode yang digunakan dalam penelitian ini adalah studi kepustakaan atau library research. Metode ini memfokuskan kegiatannya pada memanfaatkan sumber kepustakaan untuk memperoleh data penelitiannya. ${ }^{40}$ Peneliti berusaha mengumpulkan data pustaka, membaca, mencatat, serta mengolah berbagai informasi tentang pemikiran Harun Nasution mengenai pendidikan dan relevansinya dengan dunia modern khususnya di Indonesia melalui berbagai sumber terkait.

\section{Hasil dan Pembahasan}

\section{A. Relevansi Pemikiran Pendidikan Islam Harun Nasution dengan Pendidikan di Era Modern}

Relevansi dalam Kamus Besar Bahasa Indonesia (KBBI) berarti hubungan atau saling keterkaitan. Dalam pembahasan ini, penulis akan mencoba mengkaji tentang beberapa relevansi antara pemikiran atau gagasan

Seputar : Filsafat, Politik, Ekonomi, Sosial, Dan Budaya (Yogyakarta: Ar-Ruzz Media, 2004), 26.

38 Filsafat Pendidikan Islam Menuju Pembentukan Karakter, 346.

39 Filsafat Pendidikan Islam Menuju Pembentukan Karakter, 245.

40 Iwan Hermawan, Metodologi Penelitian Pendidikan: Kuantitatif, Kualitatif, Dan 
Harun Nasution dengan pendidikan di eramodern khususnya di Indonesia.

Seiring dengan perubahan dan perkembangan zaman, masalah yang dihadapi pun kian kompleks juga memunculkan masalah-masalah akhlak dan moral dikalangan peserta didik pada berbagai levelnya. Di dunia pendidikan, budaya kekerasan, ujaran kebencian, dan kemerosotan akhlak yang lainnya cukup terasa belakangan ini. Peserta didik dinilai tidak hanya kurang memiliki kesantunan baik di sekolah, di rumah dan di lingkungan masyarakat. Akan tetapi juga terlibat dalam tindak kekerasan baik antar personal maupun secara massal. Bahkan kmerosotan akhlak, moral dan etika tersebut dapat dengan mudah kita temui dalam kehidupan sehari-hari di sekitar kita saat ini.

Berdasarkan hal tersebut, inti pemikiran dari Harun Nasution yang menekankan pada pentingnya aspek moral untuk ditanamkan kepada peserta didik relevan dalam menjawab permasalahan-permasalahan yang terjadi di era modern ini, dimana fenomena kemerosotan akhlak semakin marak terjadi. Harun Nasution telah mengembangkan berbagai progam yang secara keseluruhan diarahkan kepada upaya mewujudkan tujuan tersebut, salah satunya yaitu dalam sistem pendidikan dan pengajaran yang semula dititikberatkan pada hapalan, diganti menjadi sistem diskusi dan seminar yang memungkinkan terjadinya dialog, menumbuhkan sikap kritis dan terbuka terhadap berbagai pemikiran dan pendapat orang lain sehingga kebebasan berpikir dan mengemukakan pendapat mahasiswa masih terus diterapkan hingga sekarang. Umat Islam, khususnya lingkungan IAIN, harus berani mempertanyakan tradisi pemikiran Islam yang selama ini dianggap mapan dan mengadakan terobosan-terobosan agar terhindar dari kesempitan berpikir.

Pemikiran tentang pembaharuan pendidikan Islam tersebut relevan dengan sistem pendidikan nasional tentang dasar, fungsi dan tujuan pendidikan nasional yaitu pendidikan nasional bertujuan untuk mengembangkan potensi peserta didik agar menjadi manusia yang beriman dan bertakwa kepada Tuhan 
Yang Maha Esa, berakhlak mulia, sehat, berilmu, cakap, kreatif, mandiri dan menjadi warga negara yang demokratis serta bertanggung jawab. ${ }^{41}$

Prinsip penyelenggaraan pendidikan yang baik, diperlukan dalam mencapai tujuan pendidikan. Gagasan Harun Nasution dalam penyelenggaraan pendidikan yaitu karena tujuan utama dari pendidikan Islam adalah pendidikan moral, maka metode yang sebaiknya dipakai menurut Harun Naution ialah: pemberian contoh dan teladan, nasihat, tuntunan dalam menyelesaikan persoalan, kerjasama dengan lingkungan, kerjasama dengan pendidik lainnya, tanya jawab dalam hal intelektual.

Pemikiran tentang prinsip penyelenggaraan pendidikan tersebut relevan dengan sistem pendidikan nasional tentang prinsip penyelenggaraan pendidikan nasional yang memuat agar pendidikan diselenggarakan secara demokratis dan berkeadilan serta tidak diskriminatif dengan menjunjung tinggi hak asasi manusia, nilai keagamaan, nilai kultural, dan kemajemukan bangsa dengan memberi keteladanan, membangun kemauan, dan mengembangkan kreativitas peserta didik dalam proses pembelajaran. ${ }^{42}$

Selain itu, terkait dengan perlunya kerjasama dengan lingkungan rumah dan lingkungan pergaulan anak didik dalam pembentukan moral. Hal tersebut relevan untuk diterapkan pada pendidikan era modern saat ini bahwa pendidikan merupakan tanggung jawab bersama sebab bagaimanapun persoalan moral peserta didik semestinya tidak dilimpahkan kepada pihak sekolah saja. Keterpaduan dan kerjasama antara sekolah, keluarga, masyarakat harus terus diupayakan demi tercapainya tujuan pendidikan moral.

Pemikiran Harun Nasution terkait tujuan dan kurikulum dalam pendidikan dimana materi pelajaran yang ditekankan pada aspek moral diberikan secara berkesinambungan dari yang sederhana di TK dan SD sampai kepada yang bersifat filosofis di PT, relevan untuk pendidikan di era modern saat ini dimana dalam menerapkan suatu pendekatan

\footnotetext{
41 “Salinan Undang-Undang Sisdiknas Nomor 20 Tahun 2003,” n.d, 3.

42 “Salinan Undang-Undang Sisdiknas Nomor 20 Tahun 2003.”, 4.
} 
pendidikan termasuk dalam pembagian beban belajar haruslah memperhatikan aspek psikologi peserta didik berkaitan dengan pertumbuhan dan perkembangan proses belajarnya.

Menurut Harun Nasution ada beberapa syarat-syarat yang perlu dipenuhi bagi pendidik agama antar lain yaitu: menjadi teladan, menguasai ilmu pengetahuan, mempunyai pengetahuan yang luas tentang agama selain pengetahuan yang menjadi jurusan, mempunyai pengetahuan yang seimbang dengan pengetahuan siswa.

Gagasan Harun Nasution tentang kualifikasi tenaga pendidik tersebut relevan dengan sistem pendidikan nasional tentang kewajiban pendidik dan tenaga kependidikan yaitu menciptakan suasana pendidikan yang bermakna, menyenangkan, kreatif, dinamis dan dialogis, berkomitmen secara profesional untuk meningkatkan mutu pendidikan, memberi teladan dan menjaga nama baik lembaga, profesi, dan kedudukan sesuai dengan kepercayaan yang diberikan kepadanya. ${ }^{43}$

\section{Kesimpulan}

Inti pemikiran dari Harun Nasution yang menekankan pada pentingnya aspek moral untuk ditanamkan kepada peserta didik relevan dalam menjawab permasalahan-permasalahan yang terjadi di era modern ini dimana fenomena kemerosotan akhlak semakin marak terjadi. Diantara relevansi pemikirannya yaitu: (1) Harun Nasution adalah seorang tokoh pendidikan kenamaan Indonesia, tujuan pendidikan agama menurut Harun Nasution yaitu seharusnya bukanlah sebatas pengajaran-pengajaran pengetahuan agama dan praktik-praktik ibadah semata, akan tetapi yang terpenting disamping hal tersebut adalah bagaimana membentuk peserta didik menjadi seorang yang bermoral dan berakhlak mulia, (2) kurikulum pendidikan hendaknya disusun dengan memperhatikan aspek moral, perkembangan dan pertumbuhan proses berfikir peserta didik, (3) penggunaan metode pendidikan hendaknya ditekankan pada penanaman pendidikan moral sehingga terbentuk moral yang baik dalam diri anak 
disamping tersampaikannya materi, (4) pendidik sudah seharusnya memiliki berbagai kompetensi dan senantiasa terus meningkatkan kualitasnya, (5) peserta didik merupakan seorang manusia yang harus diasah semua potensinya, baik jasmani, akal, dan yang terpenting kalbunya (hati/jiwa), pendidikan agama seharusnya menghasilkan siswa atau mahasiswa yang berjiwa agama, bukan sekedar berpengetahuan agama, sehingga terbentuk umat Islam yang mampu memfungsikan akalnya dengan sebaik-baiknya dan termotivasi untuk banyak berusaha atau dengan kata lain mampu menyeimbangkan orientasi keakhiratan dan orientasi keduniaan.

43 “Salinan Undang-Undang Sisdiknas Nomor 20 Tahun 2003.”, 13. 


\section{DAFTAR PUSTAKA}

Abdus Syakur, Polemik Harun Nasution dan H.M. Rasjidi dalam Mistisisme Islam, Ulul Albab: Jurnal Studi Islam, Vol 19, No 2 (2018) https://doi.org/10.18860/ua.v19i2.5530

Amin Abdullah, and dkk. Pendidikan Islam Dan Tantangan Globalisasi, Buah Pikiran Seputar: Filsafat, Politik, Ekonomi, Sosial, Dan Budaya. Yogyakarta: Ar-Ruzz Media, 2004.

Arbiyah Lubis, Sunnatullah dalam Pandangan Harun Nasution dan Nurcholish Madjid: Jurnal Ilmiah Islam Futura, Vol 11, No 2 (2012) DOI: http://dx.doi.org/10.22373/jiif.v11i2.51

Chailani, Muchammad. "Pemikiran Harun Nasution Tentang Pendidikan dan Relevansinya dengan Pendidikan di Era Modern”. MANAZHIM 1 (2), 45-60. 2019. https://doi.org/10.36088/manazhim.v1i2.207.

Eka Putra Wirman. “The Fallacies Of Harun Nasution's Thought Of Theology”, Journal of Islam Vol 7, No 2 (2013) DOI: 10.15642/JIIS.2013.7.2.246-267

Firdaus, Sukma Umbara Tirta. "Pembaharuan Pendidikan Islam Ala Harun Nasution (Sebuah Refleksi Akan Kerinduan 'Keemasan Islam').” El-Furqania 5, no. 2 (2017).

Harahap, Herlina. Pembaharuan Pendidikan Islam Perspektif Harun Nasution. Pontianak: STAIN Pontianak Press, 2016.

Hermawan, Iwan. Metodologi Penelitian Pendidikan: Kuantitatif, Kualitatif, Dan Mixed Methode. Kuningan: Hidayatul Qur’an, 2019.

Hidayat, Muhammad Husnol. "Harun Nasution Dan Pembaharuan Pemikiran Pendidikan Islam.” Tadris 10, no. 1 (2015).

Ibrahim. "Pemikiran Islam Kontemporer (Studi Kritis Terhadap Pemikiran Harun Nasution).” Jurnal Aqidah-Ta II, no. 2 (2016).

Khairunnas Jamal. Pemikiran Tafsir Harun Nasution (Studi tentang Pola Penafsiran Al-Qur'an dalam Karya Tulis) Jurnal Ushuludin, Vol 18, No 1 (2012)

Maragustam. Filsafat Pendidikan Islam Menuju Pembentukan Karakter. Yogyakarta: Pascasarjana FITK UIN Sunan Kalijaga Yogyakarta, 2018.

Nasution, Harun. Harun Nasuition, Islam Rasional: Gagasan Dan Pemikiran. 
Bandung: Mizan, 1996.

Nurisman. Pemikiran Filsafat Islam Harun Nasution: Pengembangan Pemikiran Islam Di Indonesia. Yogyakarta: Teras, 2012.

“Salinan Undang-Undang Sisdiknas Nomor 20 Tahun 2003,” n.d.

Suwito, and Fauzan. Sejarah Pemikiran Para Tokoh Pendidikan. Bandung: Angkasa, 2003.

Syadali, Ahmad, and dkk. Refleksi Pembaharuan Pemikiran Islam 70 Tahun Harun Nasution. Jakarta: Lembaga Studi Agama dan Filsafat, 1989.

Syakur, Abdus. "Polemik Harun Nasution-H.M. Rasjidi Dalam Falsafat Dan Teologi.” Jurnal Ilmu Ushuluddin 2, no. 4 (2015).

Yanti, Depi. “Konsep Akal Dalam Perspektif Harun Nasution.” Intelektualita 6, no. 1 (2017).

Wedra Aprison. Mendamaikan Sains dan Agama: Mempertimbangkan Teori Harun Nasution: Jurnal Pendidikan Islam Vol 4 No 2 (2015) 